() А. С. Зенкін, д.т.н., професор, О. І. Ковальов, К.т.н., докторант, О. В. Овчаренко, аспірантка, Київський національний університет технологій та дизайну, Київ, Україна

\title{
ПРОЦЕСИ В СКЛАДНИХ СИСТЕМАХ УПРАВЛІННЯ ПІДПРИЕМСТВАМИ
}

\begin{abstract}
Описано підхід до ідентифікації процесів у складних
системах організаційного управління сучасним підприємством, що розкриває складову і динамічну складність системи. Динамічна поведінка описується в термінах робіт і подій за аналогією з об'єктно-подієвим методом моделювання процесів.
\end{abstract}

\section{Ключові слова: підхід; об'єкт; процес; управління; система; модель; механізм; модель зв'язку.}

\section{Вступ}

Управління виробництвом, а також навчання і виховання, демографічне регулювання, керівництво установами, управління економікою, розподіл і використання ресурсів, управління промисловістю і сільським господарством, розвиток науки і культури, управління військами і т.д., - це все області, в яких поняття «управління» (формування доцільної поведінки системи) має зовсім інший зміст, ніж те, яке відповідає класичним уявленням. Всі перераховані системи $є$ складними - явища, які описуються великим числом параметрів - великим в тому сенсі, що відповідні рівняння і співвідношення, як правило, аналітично розв'язано бути не можуть. Це одна з причин появи терміна «складна система». Друга причина - унікальність досліджуваних систем, що призводить до ситуації, коли тривалість експериментів з ними можна порівняти з терміном життя самої системи. Відзначимо також практичну неможливість проведення «чистих дослідів» зі складними системами - їх доводиться розглядати у всьому різноманітті діючих факторів. Нарешті, ознакою складної системи виступає властивість слабкої передбачуваності поведінки [1]. Вивчення підприємств як складних систем обмежена, а іноді буває неможливим 3 огляду на те, що не можна провести натурний експеримент або повторити той чи інший експеримент. У цих умовах можливим методом дослідження є моделювання. Адекватність моделі залежить від того, наскільки правильно ідентифіковані процеси підприємства і їх взаємозв'язок між собою і зовнішнім середовищем. Це пов'язано з вибором

(C) $2016 \mathrm{p}$. 
класу математичних моделей для опису процесів. Щоб вибрати клас моделей, потрібно виділити процеси, які визначають поведінку складної системи.

\section{Постановка проблеми}

Підприємства - складні системи 3 певним статусом і стійкими внутрішніми і зовнішніми зв'язками, структурою і розподілом функцій. Управлінням називається процес формування доцільної поведінки підприємства. Управління в складних системах принципово відрізняється від того, що прийнято називати «оптимальним керуванням», тобто перекладом системи в бажаний стан по деякому оптимальному шляху. у складних організаційних системах одну з основних рис становить взаємодія виділених процесів. Ця взаємодія виникає через внесеного дослідником ділення всієї системи на процеси. щоб забезпечити при цьому функціонування всього підприємства як єдиного цілого, доводиться тим або іншим способом враховувати результат впливу одного процесу на інший. Зазвичай, така взаємодія зводиться до обміну інформацією між процесами, що здійснюється по каналах зв'язку і моделюється у вигляді схеми взаємозв'язку. Найпростіша форма - блок-схема (BlockDiagram), або діаграма послідовності (Flow Chart), карта процесу (Process Map) i iн.

За змістом і механізмом дії управління складними системами найближче до фізіологічних процесів збудження і гальмування, інакше кажучи - зов- нішнього і внутрішнього стимулювання. Прямі та зворотні зв'язки, всі види і форми впливу - не більше ніж стимули, збуджуючі чи такі, що гальмують внутрішньосистемні процеси, хід і наслідки яких в основному визначаються самою системою. Проблема управління полягає в дослідженні впливу збуджуючих і гальмуючих стимулів на функціонування підприємства і кінцеві результати його діяльності, і в використанні стимулювання для досягнення необхідної результативності [2, 3].

Таким чином, підприємство представляється у вигляді багаторівневої конструкції з взаємодіючих між собою і зовнішнім середовищем процесів. Якщо підприємства вивчаються як єдине ціле, без зазначеної структуризації (ділення на мережу процесів), вони не ідентифікуються як складні системи. Аспект складності визначається не самими підприємствами як такими, а, в основному, завданнями, які стоять перед керівниками. При цьому звичайна практика ідентифікації процесів у вигляді схеми їх взаємозв'язку представляється недостатньою. Коло завдань підприємств 3 урахуванням суттєвих технологічних, ринкових, політичних змін вимагає оцінювання динаміки взаємодії процесів. При зміні зовнішнього середовища і складу задач змінюються цілі i, відповідно, причини відхилень від цілей, також коригувальні та запобіжні дії. У зв'язку з цим представляється необхідним проаналізувати аспект складності і сформулювати рекомендації 3 управління процесами. 
Логічна цілісність системи управління підприємствами забезпечується явними або прихованими припущеннями, кожне з яких може змінюватися i, тим самим, може бути джерелом ризику.

\section{Результати проведених досліджень}

Серед функцій системи управління підприємствами виділяють: планування, організацію, оперативне управління.

Планування здійснюють для найкращого використання всіх можливостей і запобігання помилкових дій. Розрізняють планування перспективне (стратегічне) і поточне (тактичне). На стадії стратегічного планування можна розглядати питання про зміну характеристик керованої системи (системи управління підприємством). При тактичному плануванні властивості системи вважаються незмінними.

Організація полягає у встановленні взаємин між процесами, встановлення порядку i умов їх функціонування. Інакше кажучи, мова йде про структуру підприємства, розподілі функцій між підрозділами, права та обов'язки і т.д.

Оперативне управління забезпечує функціонування підприємства відповідно до наміченого плану. При цьому отримані результати безперервно порівнюють $з$ необхідними і вводять коригування. Іноді стадії тактичного планування і оперативного управління важко розділити. Цю (спільну) стадію називають оперативним плануванням, втім, іноді по-іншому.
Ідентифікація процесів не змінює характеристик керованої системи, - властивості системи залишаються незмінними. Тобто ідентифікація здійснюється на стадії оперативного планування. Що з цього випливає? Для системи управління підприємствами характерна певна невизначеність функціонування, викликана спільною дією ряду факторів, що не піддаються точному прогнозу (випадкові моменти часу появи невідповідностей, зміна вимог ринку як системи більш високого рангу і т.д.). Через це зменшується раціональна глибина оперативного планування, в тому числі ідентифікації процесів. Більш того, невизначеність робить безглуздою оптимізацію оперативних рішень. Стає доречним, навіть необхідним, досить гарні рішення, одержувані евристичними методами.

у процесно-орієнтованих стандартах ДСТУ ISO серії 9000 на системи управління якістю, вимоги оптимізації немає. I в світлі сказаного вище - бути не може. А ідентифікація процесів - це не створення моделі процесу і використання їі для знаходження оптимальних параметрів процесу (як іноді коментують деякі автори), а постійне встановлення їх тотожності тим взаємопов'язаним видам діяльності, представником яких вони (процеси) є. Міркування деяких коментаторів про оптимізацію бізнес-процесів можна розглядати як приклад підміни наукового терміна розмовною мовою, подібно до того, як кажуть про надійність, маючи на увазі, наприклад, безпеку або живучість. Це 
можна прокоментувати словами Честертона: «Якщо автор просто розважався, я не заперечую. Але якщо він щось мав на увазі, я не згоден».

Розглянемо аспект складності системи управління підприємством і, відповідно, процедуру ідентифікації процесів. У стандарті ДСTУ ISO 9000, що діє до 2015 р., дається визначення: система - сукупність взаємопов'язаних і взаємодіючих елементів. Це визначення звертає нашу увагу на два роди складності в системі: складову (мозаїка), і динамічну (шахи). Складова, або детальна складність характеризує взаємозв'язок, а динамічна - взаємодію. Іншими словами, не можна судити про складність, керуючись тільки кількістю елементів, потрібно враховувати способи їх з'єднання. Далеко не завжди вірно відзначається, що чим менше елементів входить в систему, тим простіше її зрозуміти і контролювати. Багато що залежить від динамічної складності. Динамічна складність виникає в тих випадках, коли елементи можуть вступати між собою в найрізноманітніші взаємодії.

Відповідно до ДСТУ ISO 9000:2015 року, процес $є$ сукупність взаємопов'язаних або взаємодіючих робіт (видів діяльності), яка перетворює входи на виходи. Процес можна уявити як сукупність послідовних дій, спрямованих на досягнення якого-небудь результату. Наприклад, технологічний процес, або навчально-виховний процес. В цьому випадку процесний підхід до управління визна- чається як підхід до управлінської теорії, що ґрунтується на концепції, згідно 3 якою управління $є$ безперервна серія взаємопов'язаних дій або функцій. Можна сказати, що це не системне уявлення, оскільки втрачена динамічна складність.

3 точки зору динамічної складності, процес визначається як хід будь-якого явища, що має початок і кінець, зміна станів, стадій розвитку в часі. Наприклад, процес поділу клітини, яка сама $є$ найпростішою одиницею будови живого організму, - це саме перехід зі стану з одними параметрами в стан 3 іншими параметрами. Також світовий історичний процес, або процес розвитку хвороби - це рух. У цьому сенсі використовується слово процесія - урочиста хода, хода [4]. Автор бестселера, Стівен Кові саме так визначає процес - як ріст і розвиток (зміна, оновлення). У житті кожної людини присутні послідовні стадії росту і розвитку. Дитина вчиться перевертатися на животик, сідати, потім ходити і бігати. Кожен крок важливий і вимагає часу, і жоден 3 них не може бути пропущений. Це відноситься до всіх життєвих фаз, до всіх областей розвитку, будь-то навчання грі на фортепіано або ефективному спілкуванню з колегою на роботі, або управління підприємством. Що виходить запитує Кові - коли ми намагаємося скоротити природний процес росту і розвитку? Уявіть, що ви, будучи вельми середнім гравцем в теніс, вирішили вразити оточуючих, виступаючи в змаганнях з майстрами. До 
чого це призведе? Хіба одне тільки позитивне мислення дозволить вам ефективно протистояти професіоналу? Відповідь очевидна. Просто неможливо порушувати, ігнорувати, скорочувати цей природний процес розвитку. Це суперечить природі, і спроба знайти коротку дорогу до успіху призведе лише до розчарування. Втім, ще раніше С. Бір писав, що системи можна вважати сукупністю окремих елементів і частин, але осмислити сутність системи можна тільки тоді, коли зв'язки між елементами і частинами, динамічні взаємодії всієї системи стають об'єктом дослідження.

Динамічна поведінка системи може бути представлено в термінах робіт і подій за аналогією з об'єктно-подієвим методом моделювання процесів, який зазвичай застосовується для процесів 3 непередбачуваною послідовністю дій, але з однозначно певним набором цих дій. Роботи - динамічні об'єкти, які вказують на вчинення певної одиниці роботи. Кожна робота характеризується часом ії виконання і споживаними ресурсами. Закінчення роботи в системі $€$ подією. Подією має бути не тільки закінчення роботи, а й стан процесу, що включає ці роботи. Стан процесу породжує коригувальні та запобіжні дії, що вносять зміни в процес. Події управляють ініціалізацією робіт і відзначають додавання цінності. Це додаток має бути виміряним.

\section{Висновки}

Процеси підприємства повинні розроблятися відповідно до принципів взаємозв'язку (послідовних дій) і взаємодії (зростання/розвитку). Тобто, необхідно розглядати обидва типи процесів: процеси, що розкривають складову складність і процеси, що розкривають динамічну складність системи [7]. Однак не обов'язково ідентифікувати окремо якісь особливі процеси для розкриття складової і динамічної складності системи організаційного управління. Динамічну складову можна врахувати за допомогою опису процесів, заснованого на об'єктно-подієвому методі. Якщо розглянута система - це система управління підприємством, доцільно під подіями розуміти виконання процесів (досягнення їх цілей) i одночасно - зміну стану системи, тобто додавання цінності, яке відбувається на кордонах робіт і процесів. Потрібно мати на увазі обидва аспекти складності одночасно [5]. При цьому необхідно здійснювати (а) опис властивостей процесів, так як дії будуть спрямовані на зміну цих властивостей, (б) моніторинг процесів, шляхом організації збору даних та оцінювання показників функціонування процесів, (в) ідентифікацію та ранжування всіх подій і пов'язаних з ними дій, так як слід бути готовим до ситуації, коли кілька подій відбуваються одночасно або подія відбувається в той час, коли ми відпрацьовуємо інше. 


\section{Список використаної літератури}

1. Бусленко Н. Г. Моделирование сложных систем / Н. Г. Бусленко. - М. : Изд-во «Наука», 1978. - 400 с.

2. Дружинин Г. В. Методы оценки и прогнозирования качества / Г. В. Дружинин. - М. : Радио и связь, 1982. - 160 с.

3. Дружинин В. В. Системотехника / В. В. Дружинин, Д. С. Конторов. М. : Радио и связь, 1985. - 200 с.

4. Ковалев А. И. О бедном процессе замолвите слово / А. И. Ковалев // Все о качестве. Отечественные разработки. - 2005. - Вып. 38. - С. 65-69.

5. Менеджмент якості функціонування підприємств / О. І. Ковальов, А. С. Зенкін, А. І. Хімічева. - Хмельницький : ПП ЦЮПАК, 2010. - 520 с.

6. Ковальов А. І. Показатели качества деятельности предприятий / А. І. Ковальов, А. С. Зенкін // Проблеми інформатизації та управління. -2014. - № 4(48). - С. 60-67.

7. Ковальов А. І. Процессный поход к статистическому контролю качества технологических процессов / А. І. Ковальов, А. С. Зенкін // Економіка та організація виробництва. - 2011. - № 9. - С. 54-61.

\section{References}

1. Buslenko, N. G. (1978). Modelirovanie slozhnyh sistem [Modeling of complex systems]. Moscow: Izd-vo 'Nauka' [in Russian].

2. Druzhinin, G. V. (1982). Metody ocenki i prognozirovanija kachestva [Methods of evaluation and prediction of quality]. Moscow: Radio i svjaz' [in Russian].

3. Druzhinin, V. V. \& Kontorov, D. S. (1985). Sistemotehnika [Systems engineering]. Moscow: Radio i svjaz' [in Russian].

4. Kovalev, A. I. (2005). O bednom processe zamolvite slovo [A poor process will say a word]. Journal of Vse o kachestve. Otechestvennye razrabotki. - All about the quality. Domestic developments, 38, 65-69 [in Russian].

5. Kovalov, O. I. \& Zenkin, A. S. \& Khimicheva, A. I. (2010). Menedzhment yakosti funktsionuvannia pidpryiemstv [The quality management of the enterprise functioning]. Khmelnytskyi: PP TsluPAK [in Ukrainian].

6. Kovalov, A. I. \& Zenkin, A. C. (2014). Pokazateli kachestva dejatel'nosti predprijatij [Indicators of quality of activity of enterprises]. Journal of Problemy informatyzatsii ta upravlinnia. - Problems of Informatization and management, 4(48), 60-67 [in Russian].

7. Kovalov, A. I. \& Zenkin, A. C. (2011). Processnyj pohod k statisticheskomu kontrolju kachestva tehnologicheskih procesov [Process campaign to the statistical quality control of technological processes]. Journal of Ekonomika ta orhanizatsiia vyrobnytstva. - Economics and organization of production, 9, 54-61 [in Russian].

\section{Описан подход к идентификации процессов в сложных системах организационного управления современным предприятием, раскрывающий составную и динамическую сложность системы. Динамическое поведение описывается}


в терминах работ и событий по аналогии с объектнособытийным методом моделирования процессов.

Ключевые слова: подход; объект; процесс; управление;

система; модель; механизм; модель связи.

The approach to identify processes in complex systems, organizational management, revealing a dynamic component and system complexity. Dynamic behavior described

in terms of activities and events similar to the objectevent-simulation processes.

Keywords: approach; object; process; control; system; model; mechanism; model of communication.

Рецензент - Т. Ю. Киричок, д.т.н., професор, НТУУ «КПІ імені Ігоря Сікорського»

Надійшла до редакції 16.09.16 